\title{
Robust cobalt oxide catalysts for controllable hydrogenation of carboxylic acids to alcohols
}

\author{
Song Song a, ${ }^{\dagger}$, Dong Wang ${ }^{c^{\dagger}}$, Lu Di a, Chuanming Wang c, Weili Dai a, Guangjun Wu a ${ }^{\text {a }}$, Naijia Guan ${ }^{\text {a,b }}$, \\ Landong $\mathrm{Li}^{\mathrm{a}, \mathrm{b}, *}$ \\ a School of Materials Science and Engineering \& National Institute for Advanced Materials, Nankai University, Tianjin 300350, China \\ ${ }^{\mathrm{b}}$ Key Laboratory of Advanced Energy Materials Chemistry of Ministry of Education, Collaborative Innovation Center of Chemical Science and Engineering, \\ Nankai University, Tianjin 300071, China \\ c SINOPEC, Shanghai Research Institute of Petrochemical Technology, Shanghai 201208, China
}

\section{A R T I C L E I N F}

\section{Article history:}

Received 6 October 2017

Accepted 21 November 2017

Published 5 February 2018

\section{Keywords:}

Selective hydrogenation

Carboxylic acids

Alcohols

Cobalt oxides

Reaction-controlled catalysis

\begin{abstract}
A B S T R A C T
The selective catalytic hydrogenation of carboxylic acids is an important process for alcohol production, while efficient heterogeneous catalyst systems are still being explored. Here, we report the selective hydrogenation of carboxylic acids using earth-abundant cobalt oxides through a reaction-controlled catalysis process. The further reaction of the alcohols is completely hindered by the presence of carboxylic acids in the reaction system. The partial reduction of cobalt oxides by hydrogen at designated temperatures can dramatically enhance the catalytic activity of pristine samples. A wide range of carboxylic acids with a variety of functional groups can be converted to the corresponding alcohols at a yield level applicable to large-scale production. Cobalt monoxide was established as the preferred active phase for the selective hydrogenation of carboxylic acids.
\end{abstract}

(C) 2018, Dalian Institute of Chemical Physics, Chinese Academy of Sciences. Published by Elsevier B.V. All rights reserved.

\section{Introduction}

Alcohols are known as simple but important building blocks in the fine chemistry industry and have increasing global demand. The catalytic hydrogenation of carboxylic acids with dihydrogen is the most straightforward and green process for the production of alcohols, which is a fundamental transformation in laboratory organic synthesis and is also applied on an industrial scale [1-3]. However, the low electrophilicity of the carbonyl carbon and the weak polarizability of the carbonyl group make the hydrogenation of carboxylic acids very difficult. In the past decades, the hydrogenation of carboxylic acids has been well-investigated with a focus on catalysis [4-13]. Homogeneous organometallic complexes based on ruthenium [4-6], iridium and rhodium [7], and cobalt [8], have been reported, and a delicately designed catalyst system, including metal precursor, ligand, and additive, is the key point to achieve high activity for carboxylic acid hydrogenation. The interaction of the carboxylic acid with the active transition metal center may result in the critical deactivation of the organometallic catalyst.

Heterogeneous catalysts based on platinum group metals, e.g., ruthenium [9-11] and platinum [12], have also been successfully developed for the hydrogenation of carboxylic acids. However, the selectivity toward alcohols is usually $~ 90 \%$, which is insufficient for alcohol production from carboxylic acid hydrogenation $[1,14,15]$. Moreover, the use of precious metals will undoubtedly increase the cost for the hydrogenation process. Despite current achievements, hydrogenation

\footnotetext{
* Corresponding author. Tel/Fax: +86-22-23500341; E-mail: lild@nankai.edu.cn

This work was supported by the National Natural Science Foundation of China $(21421001,21573113)$ and Sinopec Corp.

${ }^{\dagger}$ Two authors contributed equally to this work.

DOI: 10.1016/S1872-2067(17)63003-1 | http://www.sciencedirect.com/science/journal/18722067 | Chin. J. Catal., Vol. 39, No. 2, February 2018
} 
catalysts are still being explored and the efficient hydrogenation of carboxylic acids to the corresponding alcohols remains challenging.

Herein, we report partially reduced cobalt oxides as robust nonprecious catalysts for the controllable hydrogenation of carboxylic acids to the corresponding alcohols. A wide range of carboxylic acids with different functional groups can be hydrogenated to alcohols under relatively mild conditions at yields applicable to large-scale production.

\section{Experimental}

\subsection{Catalyst preparation}

The $\mathrm{Co}_{3} \mathrm{O}_{4}$ sample was prepared by a precipitation method. In a typical process, diffluent cobalt salt (cobalt nitrate, cobalt chloride, or cobalt acetate) was dissolved in $200 \mathrm{~mL}$ distilled water and a precipitator ( $1 \mathrm{~mol} / \mathrm{L}$ of $\mathrm{Na}_{2} \mathrm{CO}_{3}$ solution) was added dropwise into the cobalt salt aqueous solution under vigorous stirring until the $\mathrm{pH}$ of the mother liquid reached approximately 9 . The suspension was aged for $2 \mathrm{~h}$ with stirring at room temperature and the precipitate was collected by filtration and thoroughly washed with distilled water. The solid product was dried at $353 \mathrm{~K}$ overnight and then calcined in air at $773 \mathrm{~K}$ for $6 \mathrm{~h}$ to obtain $\mathrm{Co}_{3} \mathrm{O}_{4}$.

The as-prepared $\mathrm{Co}_{3} \mathrm{O}_{4}$ was further reduced in $5 \mathrm{vol} \% \mathrm{H}_{2} / \mathrm{Ar}$ (flow rate $=20 \mathrm{~mL} / \mathrm{min}$ ) at a designated temperature (473-773 $\mathrm{K})$ for $2 \mathrm{~h}$ and the obtained reduced cobalt oxides were labeled as $\mathrm{Co}_{3} \mathrm{O}_{4}-n$, in which $n$ indicates the reduction temperature in Kelvin. (Note: The reduced cobalt oxides were extremely active and self-ignition could occur upon contact with air. All experiments with reduced cobalt oxides should be performed in a glove box.)

\subsection{Characterization techniques}

The specific surface areas of samples were determined by $\mathrm{N}_{2}$ adsorption/desorption isotherms at $77 \mathrm{~K}$ collected on a Quantachrome iQ-MP gas adsorption analyzer. Transmission electron microscopy (TEM) images of selected samples were taken on a FEI Tecnai $\mathrm{G}^{2} \mathrm{~F} 30$ electron microscope at an acceleration voltage of $200 \mathrm{kV}$. A few drops of the alcohol suspension containing the sample were placed on a carbon-coated copper grid, followed by evaporation at ambient temperature. The temperature-programmed reduction (TPR) experiments of selected samples were performed on a chemisorption analyzer (Chemisorb 2720, Micromeritics) with 5 vol\% $\mathrm{H}_{2} / \mathrm{Ar}$ in the temperature range of $300-1000 \mathrm{~K}$ at a heating rate of 10 $\mathrm{K} / \mathrm{min}$. Prior to reduction, the sample was pretreated in $\mathrm{Ar}$ at $573 \mathrm{~K}$ for $1 \mathrm{~h}$. The X-ray diffraction (XRD) patterns of $\mathrm{Co}_{3} \mathrm{O}_{4}$ during the in situ reduction process (473-773 K) were recorded on a Thermo ARL SCINTAG X'TRA diffractometer with Anton Parr XRK 900 reaction chamber using $\mathrm{Cu}-K_{\alpha}$ radiation $(\lambda=$ $0.1541 \mathrm{~nm}$ ) at a scanning rate of $4 \% / \mathrm{min}$ in the region of $2 \theta=$ $10-80^{\circ}$. The sample chamber atmosphere was maintained under flowing $5 \mathrm{vol} \% \mathrm{H}_{2} / \mathrm{Ar}$ at a flowrate of $20 \mathrm{~mL} / \mathrm{min}$. X-ray photoelectron spectra (XPS) were recorded on a Thermo Scien- tific ESCALAB 250Xi spectrometer using a monochromatic $\mathrm{Al}-K_{\alpha} \mathrm{X}$-ray source $(h v=1486.6 \mathrm{eV})$ as the excitation source. The $\mathrm{Co}_{3} \mathrm{O}_{4}$ sample was reduced in situ in the reaction chamber, evacuated, and transferred for analysis under vacuum. All spectra were recorded by using an aperture slot of $300 \times 700$ micrometers. Accurate binding energies $( \pm 0.1 \mathrm{eV})$ were determined with respect to the position of the adventitious $\mathrm{C} 1 \mathrm{~s}$ peak at $284.8 \mathrm{eV}$.

\subsection{Catalytic evaluation and product analysis}

The hydrogenation of carboxylic acids or other substrates was performed in a high-pressure stainless-steel autoclave (Xinyuan Chemical Machinery, Series CJK, $300 \mathrm{~mL}$ ) with a maximum stirring rate of $1500 \mathrm{r} / \mathrm{min}$. In a typical experiment, $0.2 \mathrm{~g}$ of catalyst (or without catalyst for the control experiment), $3 \mathrm{mmol}$ of the substrate, and $100 \mathrm{~mL}$ alkane solvent ( $n$-hexane, $n$-heptane, $i$-octane, or $n$-dodecane) were well mixed in the autoclave and purged with pure nitrogen at room temperature. The gas supply and discharge were carried out manually through needle valves. The autoclave was rapidly heated to the desired temperature and hydrogen was introduced at 2 MPa to initiate the reaction. The reaction pressure was kept at $2 \mathrm{MPa}$ with a small negative deviation $(\sim 0.2 \mathrm{MPa})$ owing to the consumption of hydrogen. Samples of the liquid phase were continuously taken through a sampling tube with a filter at certain intervals. The stirring rate was kept at $750 \mathrm{r} / \mathrm{min}$ during the reaction.

The liquid organic products were analyzed by gas chromatography (Shimadzu GC-2010) and gas chromatography-mass spectrometry (Shimadzu GCMS-QP2010 SE), both with a RXI-5MS column (30 m, $0.25 \mathrm{~mm}$ internal diameter, stationary phase thickness $0.25 \mu \mathrm{m})$. $n$-Eicosane was used as an internal standard for quantification through the internal standard method. For the hydrogenation of dioic acids, the substrates and liquid organic products were analyzed by high-performance liquid chromatography (Shimadzu LC-20AT) with a Carbomix H-NP column $(7.8 \times 300 \mathrm{~mm}$, stationary phase thickness $10 \mu \mathrm{m})$. The gas products were analyzed with a mass spectrometer (Pfeiffer Omnistar GSD 320).

For recycling tests, the catalyst sample was separated from the liquid phase by configuration in the glove box (without a washing step) and then mixed with the desired amount of stearic acid for the next reaction cycle.

\subsection{Computational methods and modeling}

All the spin-polarized calculations were performed with the Perdew-Burke-Ernzerhof (PBE) functional using the VASP software [16,17]. The project-augmented wave (PAW) method was used to represent the core-valence electron interaction. The valence electronic states were expanded in the plane wave basis sets with energy cutoff at $450 \mathrm{eV}$, and the occupancy of the one-electron states was calculated using Gaussian smearing. The ionic degrees of freedom were relaxed using the BFGS minimization scheme until the Hellman-Feynman forces on each ion were less than $0.3 \mathrm{eV} / \mathrm{nm}$. Transition states were 
searched using a dimer method [18,19], and were verified when (i) all forces on the atoms vanished; and (ii) the total energy was a maximum along the reaction coordination but a minimum with respect to the rest of the degrees of freedom. The dipole correction was applied throughout the calculations to take the polarization effect into account.

The CoO (111) surface was modeled as a four-Co-layer $p(4 \times 4)$ periodic slab consisting of 128 atoms, and a corresponding $1 \times 1 \times 1 \mathrm{k}$-points mesh was used during calculations. Atoms in the bottom two layers were fixed, and all other atoms were fully relaxed. For the calculations for $\mathrm{CoO}$, the on-site coulomb correction was used to describe the electronic and geometric structure, i.e., the so-called DFT+U method [20,21]. The effective $\mathrm{U}$ value was set to $7 \mathrm{eV}$ for Co $3 d$ orbitals, as suggested in previous works [21]. In addition, we tested the effect of the spin state of $3 d$ electrons in $\mathrm{Co}^{2+}$ in the optimization of $\mathrm{CoO}$, and found that the high-spin antiferromagnetic arrangement was the most stable state, which was consistent with literature reports $[22,23]$.

For the model construction, two types of $\mathrm{CoO}$ (111) surface were initially considered, as shown in Fig. S1. Model I was exposed and had a fully reduced upper surface (Co-terminated) and a fully oxidized bottom surface (O-terminated), whereas Model II was terminated with two identical partially oxidized (or reduced) surfaces. Thermodynamic calculations showed that the surface energy of Model II was $1.23 \mathrm{~J} / \mathrm{m}^{2}$ more stable than that of Model I. Thus, Model II was used as the theoretical model for the $\mathrm{CoO}$ (111) surface to explore the reaction mechanism throughout the calculations. The detailed intermediate structures (including transition states) for the optical pathway are shown in Fig.s S2 \& S3.

\section{Results and discussion}

Biomass-derived stearic acid $\left(\mathrm{C}_{17} \mathrm{H}_{35} \mathrm{COOH}\right)$ was initially chosen as a model substrate and the hydrogenation of stearic acid was investigated by using various transitional metal oxides as catalysts. As shown in Table 1, the selective hydrogenation of stearic acid to 1-octadecanol was achieved by using simple transition metal oxides such as $\mathrm{Fe}_{3} \mathrm{O}_{4}, \mathrm{Co}_{3} \mathrm{O}_{4}$, and $\mathrm{NiO}$ as catalysts. $\mathrm{Co}_{3} \mathrm{O}_{4}$ appeared to be a more active hydrogenation cata- lyst with a reaction rate of $1.2 \mathrm{mmol} / \mathrm{h} / \mathrm{g}$ at $473 \mathrm{~K}$ and under 2 MPa hydrogen, comparable with platinum group metal catalysts $\mathrm{Pd} / \mathrm{C}(0.6 \mathrm{mmol} /(\mathrm{h} \cdot \mathrm{g}))$ and Pt/C (1.8 mmol/(h.g)). Furthermore, perfect selectivity of $>99.9 \%$ toward the alcohol was observed over $\mathrm{Co}_{3} \mathrm{O}_{4}$, which was superior to $\mathrm{Pd} / \mathrm{C}(89.6 \%)$ and $\mathrm{Pt} / \mathrm{C}$ (97.9\%). The precursors for the preparation of $\mathrm{Co}_{3} \mathrm{O}_{4}$ can influence the catalytic performance of cobalt oxides to some extent (Fig. S4). The $\mathrm{Co}_{3} \mathrm{O}_{4}$ was further treated in hydrogen at different temperatures to derive partially reduced cobalt oxides for the hydrogenation of stearic acid. The activity of pristine $\mathrm{Co}_{3} \mathrm{O}_{4}$ was significantly enhanced through partial reduction and the perfect selectivity toward 1-octadecanol was well preserved. Typically, a high reaction rate of $7.3 \mathrm{mmol} /(\mathrm{h} \cdot \mathrm{g})$ with $>99.9 \%$ 1-octadecanol selectivity was obtained on $\mathrm{Co}_{3} \mathrm{O}_{4}$ reduced at $573 \mathrm{~K}$, i.e., $\mathrm{Co}_{3} \mathrm{O}_{4}-573$. Because the reaction occurs on the surface of the oxides, the surface specific activity was calculated and the intrinsic activity of $\mathrm{Co}_{3} \mathrm{O}_{4}-573 \quad 0.447$ $\left.\mathrm{mmol} /\left(\mathrm{h} \cdot \mathrm{m}^{2}\right)\right)$ was more than 30 times higher than that of $\mathrm{Co}_{3} \mathrm{O}_{4}\left(0.014 \mathrm{mmol} /\left(\mathrm{h} \cdot \mathrm{m}^{2}\right)\right)$. Undoubtedly, partially reduced cobalt oxides were robust catalysts for the selective hydrogenation of stearic acid to 1-octadecanol and the reduction treatment in hydrogen was the key step for achieving the high activity. According to the time-dependent behavior of stearic acid hydrogenation (Fig. S5), the complete conversion of stearic acid to 1-octadecanol can be achieved before the further conversion of 1-octadecanol to alkanes. Hot filtration experiments (Fig. S6) revealed the heterogeneous nature of the stearic acid hydrogenation catalytic reaction by $\mathrm{Co}_{3} \mathrm{O}_{4}-573$, which also exhibited good recycling ability (Fig. S7).

The effects of the reaction temperature on the stearic acid hydrogenation were investigated. As expected, increasing the reaction temperature significantly promoted the conversion of stearic acid over $\mathrm{Co}_{3} \mathrm{O}_{4}-573$. Kinetic plots of the stearic acid conversion (Fig. S8) indicated a linear increase in stearic acid conversion with reaction time at the early stage of the reaction and perfect selectivity toward 1-octadecanol was obtained before the total conversion of stearic acid, independent of the reaction temperatures. After the total conversion of stearic acid, the product 1-octadecanol was further converted to $n$-octadecane and $n$-heptadecane (Fig. S6) through a hydrogenolysis route [24-27]. Therefore, the selective hydrogenation of

Table 1

Catalysts and their performance in the hydrogenation of stearic acid to 1-octadecanol a.

\begin{tabular}{|c|c|c|c|c|c|}
\hline Catalyst & $\begin{array}{c}S_{\mathrm{BET}} \\
\left(\mathrm{m}^{2} / \mathrm{g}\right) \\
\end{array}$ & Phase & $\begin{array}{l}\text { Reaction rate } \\
(\mathrm{mmol} /(\mathrm{h} \cdot \mathrm{g}))\end{array}$ & $\begin{array}{c}\text { Selectivity }{ }^{b} \\
(\%)\end{array}$ & $\begin{array}{l}\text { Specific activity } \\
\left(\mathrm{mmol} /\left(\mathrm{h} \cdot \mathrm{m}^{2}\right)\right)\end{array}$ \\
\hline $\mathrm{Fe}_{3} \mathrm{O}_{4}$ & 75.5 & $\mathrm{Fe}_{3} \mathrm{O}_{4}$ & $1.0^{\mathrm{c}}$ & $>99.9$ & 0.012 \\
\hline $\mathrm{NiO}$ & 98.9 & $\mathrm{NiO}$ & 0.9 & $>99.9$ & 0.008 \\
\hline $\mathrm{Co}_{3} \mathrm{O}_{4}$ & 83.2 & $\mathrm{Co}_{3} \mathrm{O}_{4}$ & 1.2 & $>99.9$ & 0.014 \\
\hline $\mathrm{Co}_{3} \mathrm{O}_{4}-473$ & 71.0 & $\mathrm{Co}_{3} \mathrm{O}_{4}$ & 2.2 & $>99.9$ & 0.031 \\
\hline $\mathrm{Co}_{3} \mathrm{O}_{4}-573$ & 16.3 & $\mathrm{CoO}$ & 7.3 & $>99.9$ & 0.447 \\
\hline $\mathrm{Co}_{3} \mathrm{O}_{4}-573^{\mathrm{d}}$ & 16.9 & $\mathrm{CoO}$ & 7.4 & $>99.9$ & 0.438 \\
\hline $\mathrm{Co}_{3} \mathrm{O}_{4}-673$ & 12.6 & $\mathrm{CoO} \& \mathrm{Co}$ & 6.4 & $>99.9$ & 0.508 \\
\hline $\mathrm{Co}_{3} \mathrm{O}_{4}-773$ & 12.1 & Co & 1.7 & $>99.9$ & 0.141 \\
\hline $\mathrm{Pd} / \mathrm{C}^{\mathrm{e}}$ & 223.6 & - & 0.6 & 89.6 & 0.003 \\
\hline $\mathrm{Pt} / \mathrm{C}^{\mathrm{f}}$ & 219.7 & 一 & 1.8 & 97.9 & 0.008 \\
\hline
\end{tabular}

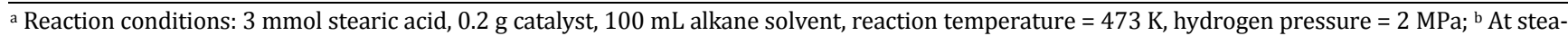
ric acid conversion of $\sim 10 \%$, closest time point employed; c Serious deactivation observed after reaction for 3 h; ${ }^{\mathrm{d}}$ Repeated experiment; e $5 \%$ Pd on activated carbon from Alfa Aesar; ${ }^{\mathrm{f}} 5 \%$ Pt on activated carbon from Alfa Aesar. 
stearic acid to 1-octadecanol over $\mathrm{Co}_{3} \mathrm{O}_{4}-573$ was realized through a reaction control process. The apparent activation energies, calculated by using the Arrhenius equation (Fig. S7), were 70 and $85 \mathrm{~kJ} / \mathrm{mol}$ for the stearic acid hydrogenation to 1-octadecanol and subsequent 1-octadecanol hydrogenolysis over $\mathrm{Co}_{3} \mathrm{O}_{4}-573$, respectively.

To establish the structure-activity relationship in the selective hydrogenation of stearic acid, a series of spectroscopic characterization techniques were performed on the cobalt oxide catalysts. In situ XRD patterns (Fig. 1(a)) revealed that the bulk phase changed from $\mathrm{Co}_{3} \mathrm{O}_{4}$ (JCPDS 43-1003) to $\mathrm{CoO}$ (JCPDS 43-1004) and then to metallic cobalt (JCPDS 05-0727) during the reduction of $\mathrm{Co}_{3} \mathrm{O}_{4}$ at increasing temperatures. The temperature-programmed reduction by hydrogen $\left(\mathrm{H}_{2}\right.$-TPR) profile of $\mathrm{Co}_{3} \mathrm{O}_{4}$ (Fig. 1(b)) revealed a two-stage reduction of the cobalt species, i.e., the reduction of $\mathrm{Co}^{3+}$ to $\mathrm{Co}^{2+}$ at $500-700$ $\mathrm{K}(\mathrm{H} / \mathrm{Co} \approx 2 / 3)$ and the reduction of $\mathrm{Co}^{2+}$ to $\mathrm{Co}^{0}$ at $600-800 \mathrm{~K}$ $(\mathrm{H} / \mathrm{Co} \approx 2 / 1)[28,29]$. For $\mathrm{Co}_{3} \mathrm{O}_{4}-573$, the dominant reduction of $\mathrm{Co}^{2+}$ to $\mathrm{Co}^{0}$ at $600-900 \mathrm{~K}(\mathrm{H} / \mathrm{Co} \approx 2 / 1)$ was observed in the $\mathrm{H}_{2}$-TPR profile [30]. The results from the XRD and $\mathrm{H}_{2}$-TPR analysis suggested that the pristine hexagonal $\mathrm{Co}_{3} \mathrm{O}_{4}$ was transformed into cubic $\mathrm{CoO}$ upon hydrogen reduction at $573 \mathrm{~K}$. The surface states of the cobalt oxides were further investigat- (a)

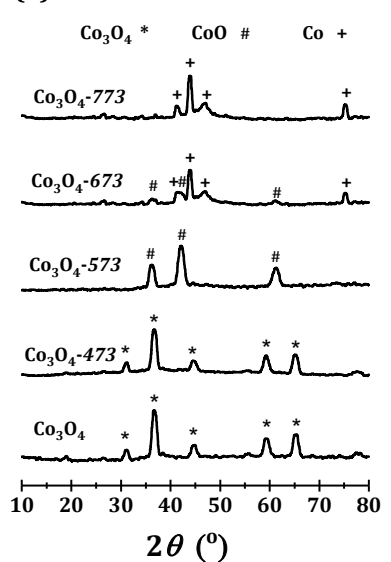

(c)

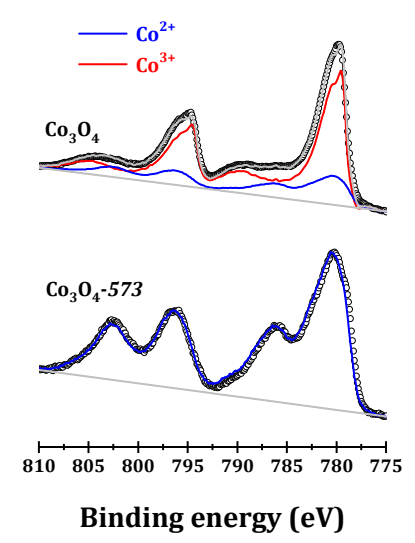

(b)
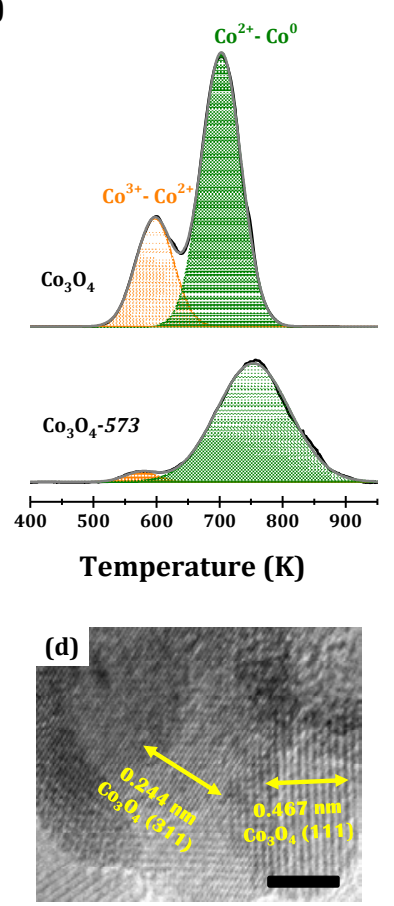

(e)

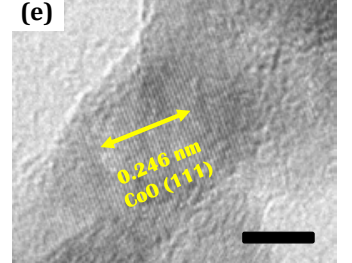

Fig. 1. Characterization of cobalt-based catalysts employed in this study (a) In situ XRD patterns of $\mathrm{Co}_{3} \mathrm{O}_{4}$ during hydrogen reduction; (b) $\mathrm{H}_{2}$-TPR profiles of $\mathrm{Co}_{3} \mathrm{O}_{4}$ and $\mathrm{Co}_{3} \mathrm{O}_{4}-573$; (c) XPS of $\mathrm{Co}_{3} \mathrm{O}_{4}$ and $\mathrm{Co}_{3} \mathrm{O}_{4}-573$; High-resolution TEM images of $\mathrm{Co}_{3} \mathrm{O}_{4}(\mathrm{~d})$ and $\mathrm{Co}_{3} \mathrm{O}_{4}-573$ (e). Scale bar $=$ $5 \mathrm{~nm}$. ed by XPS analysis. As shown in Fig. 1(c), binding energy values at 794.7 and $779.7 \mathrm{eV}$ corresponding to Co $2 p_{1 / 2}$ and $2 p_{3 / 2}$ of $\mathrm{Co}^{3+}$ and/or $\mathrm{Co}^{2+}$ were observed for $\mathrm{Co}_{3} \mathrm{O}_{4}$. The satellite features at $\sim 805$ and $\sim 786 \mathrm{eV}$ indicated the presence of $\mathrm{Co}^{2+}[31]$, and a mixture of $\mathrm{Co}^{2+}$ and $\mathrm{Co}^{3+}$ with a $\mathrm{Co}^{2+} / \mathrm{Co}^{3+}$ ratio of $\sim 1 / 3$ (owing to surface enrichment of $\mathrm{Co}^{3}+$ in $\mathrm{Co}_{3} \mathrm{O}_{4}$ ) was obtained according to the nonlinear least-squares fitting results. Through the reduction in hydrogen at $573 \mathrm{~K}$, exclusive $\mathrm{Co}^{2+}$ is observed for $\mathrm{Co}_{3} \mathrm{O}_{4}-573$. The ratio of $\mathrm{Co} / 0$ was measured to be $1 / 1$, which confirmed the homogeneous distribution of cobalt and oxygen species in stoichiometric CoO. The morphology and lattice structure of the cobalt oxides were investigated by electron microscopy. The pristine $\mathrm{Co}_{3} \mathrm{O}_{4}$ samples appeared to be nanoparticles or nanorods with a size of several tens of nanometers. Hydrogen reduction at $573 \mathrm{~K}$ could induce the growth of nanoparticles or nanorods to some extent (Fig. S11), accompanied by the decrease in surface area (Table 1). In the high-resolution transmission electron microscope (TEM) image of $\mathrm{Co}_{3} \mathrm{O}_{4}$ (Fig. 1(d)), adjacent lattice distances of 0.467 and $0.244 \mathrm{~nm}$ were observed, corresponding to the (111) and (311) planes, respectively [32-34]. For $\mathrm{Co}_{3} \mathrm{O}_{4}-573$, the typical adjacent lattice distance was measured to be $0.246 \mathrm{~nm}$, corresponding to the (111) plane in cubic $\mathrm{CoO}$ [34].

On the basis of the above-mentioned characterization and catalytic results, the pristine $\mathrm{Co}_{3} \mathrm{O}_{4}$ could be partially reduced to pure-phase nanostructured $\mathrm{CoO}$ under controlled conditions and the as-obtained $\mathrm{Co}_{3} \mathrm{O}_{4}-573$ was established as a robust catalyst for the selective hydrogenation of stearic acid to 1-octadecanol. Heterogeneous cobalt catalysts have been reported to be very active in several important reactions, e.g., carbon monoxide oxidation [32], oxygen evolution reaction [35], electroreduction of carbon monoxide [36], alcohol oxidation and nitroarenes hydrogenation $[37,38]$. The structure sensitivity of reactions on cobalt-based catalysts is widely acknowledged and has triggered significant debates $[32,33,35-40]$. In this study, CoO was definitely identified as the active species for the hydrogenation reaction. Hereafter, $\mathrm{CoO}$ (111) is used as a model surface for stearic acid hydrogenation and the reaction pathway was investigated through first-principles periodic density functional theory (DFT) calculations.

To convert carboxylic acids into alcohols, a few hydrogenation $(+\mathrm{H})$ and $\mathrm{C}-\mathrm{O}$ dissociation (dis) steps that proceed in the right sequence are required. The optimal pathways for the selective conversion of stearic acid into 1-octadecanol (blue), n-octadecane (green), and $n$-heptadecane (yellow) on the CoO (111) surface are shown in Fig. 2. As the stearic acid adsorbs on the surface, the direct dissociation of both the $\mathrm{C}=\mathrm{O}$ and the $\mathrm{C}-\mathrm{OH}$ bonds are not favored thermodynamically. Alternatively, the hydrogenation step proceeds first with a $\mathrm{H}$ atom preferentially bonding at the $\alpha-\mathrm{C}$ site instead of the carbonyl oxygen, overcoming a barrier of $0.96 \mathrm{eV}$. Then, the removal of the $\mathrm{OH}$ group is ready to occur with a small barrier $(0.36 \mathrm{eV})$ and large energy release $(-0.62 \mathrm{eV})$, generating the surface-adsorbed stearic aldehyde intermediate. By further saturating the $\mathrm{C}=0$ bond with two $\mathrm{H}$ atoms, whereby the $\alpha-\mathrm{C}$ site again has the priority over the carbonyl oxygen, the 1-octadecanol is gener- 


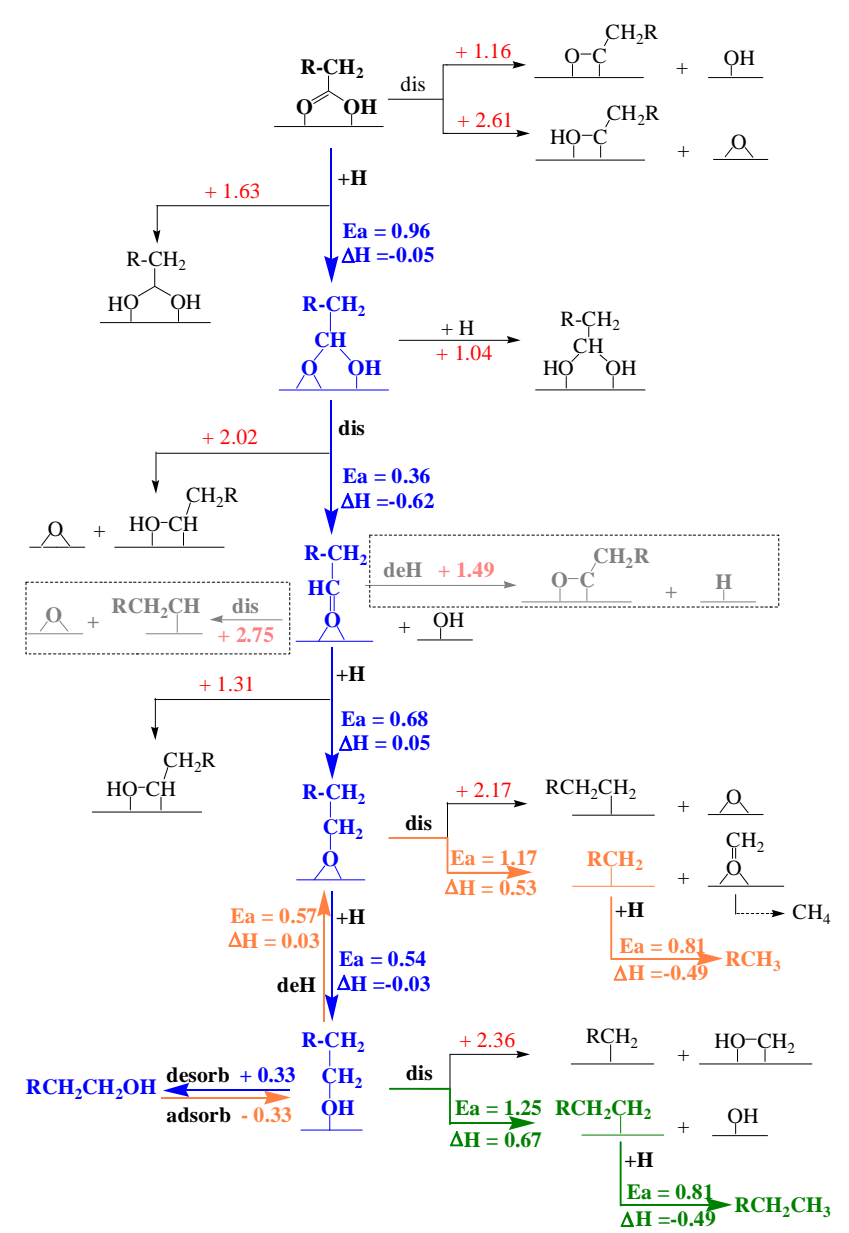

Fig. 2. Proposed reaction mechanism for stearic acid hydrogenation on the CoO (111) surface using DFT calculations. The blue arrows indicate the reaction route for 1-octadecanol generation, whereas the green and yellow arrows are for $n$-octadecane and $n$-heptadecane production, respectively. Other disfavored pathways are indicated by dashed arrows. The reaction energetics, including the reaction barriers for the favored pathways, are also listed.

ated. The conversion of 1-octadecanol into alkanes proceeds through one and/or two elementary steps that are in common with the 1-octadecanol generation pathway, and then splits into two branches yielding the $n$-octadecane and $n$-heptadecane. For the production of $n$-octadecane, the $\mathrm{C}-\mathrm{O}$ bond cleavage starts as the 1-octadecanol adsorbs on the surface by direct detachment of the $\mathrm{OH}$ group. For the generation of $n$-heptadecane, the $\mathrm{C}-\mathrm{C}$ bond breaks between the $\alpha$-C and $\beta-C$ of the deprotonated 1-octadecanol species, forming the heptadecyl group and formaldehyde on the surface. Afterwards, the as-formed octadecyl and heptadecyl species can be hydrogenated into alkanes by overcoming a reaction barrier of $0.81 \mathrm{eV}$. We also investigated other possible pathways for the production of alkanes, which were all proven to be thermodynamically prohibited on the $\mathrm{CoO}$ (111) surface (dashed squares in Fig. 2).

Kinetically, as driven by the favorable energetics, it was expected that the conversion of stearic acid into 1-octadecanol would be quick and efficient, although the computed effective barrier was slightly higher than the experimental value (0.96 vs
$0.73 \mathrm{eV}$ ). In contrast, in the hydrogenolysis process, the bond breaking of both the $\mathrm{C}-\mathrm{O}$ and $\mathrm{C}-\mathrm{C}$ bonds costs a lot energy (endothermic 0.67 and $0.53 \mathrm{eV}$, respectively) with high barriers of $\sim 1.2 \mathrm{eV}$. Therefore, the branching reaction of alkanes production would be temporarily blocked ( $\sim 0 \%$ selectivity) as long as the main route of 1-octadecanol production proceeded. The subsequent hydrogenolysis of 1-octadecanol started to emerge only when the stearic acid was exhausted in the system ( $100 \%$ conversion), which was consistent with the experimental observations shown in Fig. S5. Therefore, our DFT results demonstrate that $\mathrm{CoO}(111)$ is a good catalyst for the hydrogenation of stearic acid, and the selective hydrogenation to alcohols can be realized by controlling the concentration of acid substrates.

Inspired by the successful catalysis of the partially reduced cobalt oxides in the model reaction, we further investigated the selective hydrogenation of a wide range of carboxylic acids with different structures and functional groups (Table 2 \& Fig. S12). As expected, $\mathrm{Co}_{3} \mathrm{O}_{4}-573$ exhibited high activity in most cases and appeared to be an efficient catalyst for the controllable hydrogenation of various carboxylic acid substrates. For the hydrogenation of biomass-derived saturated fatty acids, saturated fatty alcohols were obtained with yields of $>97.5 \%$ (Entry 1-7). We also performed stearic acid hydrogenation on a larger scale (10 mmol stearic acid) and the isolated yield was determined to be $95.8 \%$ (Fig. S10), in accordance with the GC yield (97.9\%). In the case of oleic acid, the hydrogenation of the carbon-carbon double bond occurred before the hydrogenation of the carbon-oxygen bond and 1-octadecanol was obtained as the final product with a yield of $>99.9 \%$ (Entry 8, Fig. S12). The hydrogenation of cycloalkyl carboxylic acids, i.e., cyclopentaneand cyclohexane-carboxylic acid, proceeded in slightly lower yields than the straight-chain fatty acids and cycloalkyl alcohols, which were produced in quantitative yields (Entry 9 \& 10). If the carbon atom in the cycloalkyl ring was substituted with an oxygen atom, the derivatives, e.g., tetrahydro-furan-3-carboxylic acid and tetrahydropyran-4-carboxylic acid, also smoothly underwent hydrogenation and the desired alcohols were produced with the epoxy structure well preserved (Entry $11 \& 12$ ). The hydrogenation of carboxylic acid in the presence of a hydroxyl group, e.g., 4-hydroxyhexanecarboxylic acid, occurred to produce the corresponding 4-(hydroxymethyl) cyclohexanol in quantitative yield (Entry 13). A very interesting example was the hydrogenation of monomethyl adipate, i.e., a carboxylic acid in the presence of an ester group, to methyl 6-hydroxyhexanoate (Entry 14). The carboxyl group was hydrogenated to a carbinol group and the ester group was well preserved, by which the hydrogenation of the ester group is easier then the carboxyl group [8]. DFT calculations revealed that the carboxyl group adsorbs more easily on CoO (111) (adsorption energy: -1.11 $\mathrm{eV}$ ) than the ester group (adsorption energy: $-0.84 \mathrm{eV}$ ). That is, 4-monomethyl adipate adsorbs on the $\mathrm{CoO}$ (111) surface through the carboxyl group. Moreover, owing to the influence from thermodynamic entropy at a reaction temperature of 473 $\mathrm{K}(\sim 0.9 \mathrm{eV})$, the adsorption of the ester group on CoO (111) was difficult, which hindered its hydrogenation. The selective 
Table 2

Controllable catalytic hydrogenation of biomass-derived and other carboxylic acids to corresponding alcohols a.

\begin{tabular}{|c|c|c|c|c|c|c|c|c|c|c|c|c|c|}
\hline Entry & Substrate & Product & $\begin{array}{c}\text { Temp. } \\
\text { (K) }\end{array}$ & $\begin{array}{l}\text { Time } \\
\text { (h) }\end{array}$ & $\begin{array}{l}\text { Select. } \\
(\%)^{\mathrm{b}}\end{array}$ & $\begin{array}{l}\text { Yield } \\
(\%)^{\mathrm{c}}\end{array}$ & $\begin{array}{l}\text { En- } \\
\text { try }\end{array}$ & Substrate & Product & $\begin{array}{l}\text { Temp. } \\
\text { (K) }\end{array}$ & $\begin{array}{l}\text { Time } \\
\text { (h) }\end{array}$ & $\begin{array}{l}\text { Select. } \\
(\%)^{\mathrm{b}}\end{array}$ & $\begin{array}{l}\text { Yield } \\
(\%)^{\mathrm{c}}\end{array}$ \\
\hline 1 & & & 473 & 3 & 98.3 & 98.3 & $13^{\mathrm{d}, \mathrm{e}}$ & & & 453 & 6 & $>99.9$ & $>99.9$ \\
\hline 2 & & & 473 & 2.5 & $>99.9$ & 97.7 & $14^{\mathrm{f}}$ & & & 473 & 6 & $>99.9$ & $>99.9$ \\
\hline 3 & & & 473 & 2.5 & $>99.9$ & 98.8 & 15 & & & 433 & 10 & 98.1 & 98.1 \\
\hline 4 & & & 473 & 2.5 & 97.8 & 97.8 & 16 & & & 433 & 6.5 & 97.8 & 97.8 \\
\hline 5 & & & 473 & 2.5 & 98.9 & 98.9 & 17 & & & 433 & 8.5 & 94.6 & 95.6 \\
\hline 6 & & & 473 & 9 & 98.7 & 98.7 & $18^{d}$ & & & 423 & 14 & $86.1^{\mathrm{g}}$ & 86.1 \\
\hline 7 & & & 473 & 2 & $>99.9$ & $>99.9$ & $19^{\mathrm{f}}$ & & & 453 & 7 & $>99.9$ & 99.6 \\
\hline 8 & & & 473 & 6 & $>99.9$ & $>99.9$ & $20^{\mathrm{f}}$ & & & 483 & 9.5 & 98.5 & 98.5 \\
\hline 9 & & & 473 & 10 & $>99.9$ & $>99.9$ & $21^{\mathrm{f}}$ & & & 483 & 6.5 & 96.1 & 96.1 \\
\hline 10 & & & 473 & 10 & $>99.9$ & $>99.9$ & $22^{d, f}$ & & & 463 & 10 & 94.8 & 94.8 \\
\hline 11 & & & 473 & 9 & $>99.9$ & $>99.9$ & $23^{f}$ & & & 483 & 10 & $>99.9$ & $>99.9$ \\
\hline 12 & & & 473 & 10 & 98.9 & 98.9 & & & & & & & \\
\hline
\end{tabular}

a Reaction conditions: $3 \mathrm{mmol}$ substrate, $0.2 \mathrm{~g} \mathrm{Co}_{3} \mathrm{O}_{4}-573,100 \mathrm{~mL}$ alkane solvent, hydrogen pressure $=2 \mathrm{MPa}$, unless otherwise stated; ${ }^{\mathrm{b}}$ When maximal product yield is obtained; ${ }^{c} \mathrm{GC}$ yields, carbon balance $>95 \%$; ${ }^{\mathrm{a}}$ Hydrogen pressure $=4 \mathrm{MPa}$; e Substrate in trans configuration, product enantioselectivity: trans/cis > 99\%; ${ }^{\mathrm{f}}$ Dioxane as solvent; $\mathrm{g}$ Ethyl cyclohexane (13.9\%) observed as byproduct.

hydrogenation of aromatic acids, i.e., phenylpropionic acid and phenylbutyric acid, can proceed at a low temperature of $433 \mathrm{~K}$, leading to the formation of phenylpropanol and phenylbutanol in good yields (Entry 15 \& 16). The cinnamic acid underwent a preferential hydrogenation of the carbon-carbon double bond, followed by hydrogenation to phenylpropanol (Entry 17), similar to the case of oleic acid. The hydrogenation of phenylacetic acid did not lead to the formation of phenethyl alcohol as the xpected product. Instead, the aromatic hydrogenation products cyclohexylethanol (86.1\%) and ethyl cyclohexane (13.9\%) were formed (Entry 18). Clearly, the synergy effects can effectively activate the benzene ring and lead to the products from hydrogenation of the benzene ring. With an oxygen insertion between the carboxyl and the benzene ring, the selective hydrogenation of 2-methoxyphenylaceticacid was successfully performed with both the benzene ring and methoxy groups well preserved (Entry 19). Moreover, the hydrogenation of dioic acids, i.e., adipic acid and suberic acid, was achieved through a step-by-step process and the diols were obtained as the final products in good yields (Entry 20-22). An esterification-hydrogenolysis process with ring formation-opening was observed during the conversion of adipic acid (Fig. S12). The hydrogenation of succinic acid proceeded through a dehydration-decarbonylation route, resulting in $\gamma$-butyrolactone instead of 1, 4-butanediol as the final product in a quantitative yield of $>99.9 \%$, (Entry 23; Fig. S12). The further hydrogenolysis of $\gamma$-butyrolactone to 1,4-butanediol did not occur under the employed reaction conditions because the five-membered ring $\gamma$-butyrolactone was very stable against ring-opening. The $\mathrm{Co}_{3} \mathrm{O}_{4}-573$ catalyst was finally employed for the hydrogenation of carboxylic acids with halide, nitrile, or keto groups. The $\mathrm{Co}_{3} \mathrm{O}_{4}-573$ was not tolerant to these groups, and nonselective hydrogenations occurred (not shown here).

\section{Conclusions}


Cobalt oxides were developed as cheap and abundant heterogeneous catalysts for the controllable hydrogenation of carboxylic acids. Partial reduction by hydrogen dramatically promoted the activity of pristine cobalt oxides. A wide range of carboxylic acids with certain functional groups were selectively hydrogenated to the corresponding alcohols using molecular hydrogen as the reductant at yields applicable to large-scale production. Spectroscopic analysis and theoretical calculation results revealed that cobalt monoxide was the preferred catalyst for the selective hydrogenation of carboxylic acids, which underwent a reaction-controlled process.

\section{Supporting Information}

More characterization and catalytic results of cobalt oxides in the selective hydrogenation of carboxylic acids.

\section{References}

[1] S. Nishimura, Handbook of heterogeneous Catalytic Hydrogenation for Organic Synthesis, Wiley, New York, 2001.

[2] P. A. Dub, T. Ikariya, ACS Catal., 2012, 2, 1718-1741.

[3] J. Pritchard, G. A. Filonenko, R. van Putten, E. J. M. Hensen, E. A. Pidko, Chem. Soc. Rev., 2015, 44, 3808-3833.

[4] F. M. A. Geilen, B. Engendahl, M. Hölscher, J. Klankermayer, W. Leitner, J. Am. Chem. Soc., 2011, 133, 14349-14358.

[5] T. Stein, M. Meuresch, D. Limper, M. Schmitz, M. Hölscher, J. Coetzee, D. J. Cole-Hamilton, J. Klankermayer, W. Leitner, J. Am. Chem. Soc., 2014, 136, 13217-13225.

[6] X. J. Cui, Y. H. Li, C. Topf, K. Junge, M. Beller, Angew. Chem. Int. Ed., 2015, 54, 10596-10599.

[7] T. P. Brewster, A. J. M. Miller, D. M. Heinekey, K. I. Goldberg, J. Am. Chem. Soc., 2013, 135, 16022-16025.

[8] T. J. Korstanje, J. I. van der Vlugt, C. J. Elsevier, B. de Bruin, Science, 2015, 350, 298-302.

[9] J. E. Carnahan, T. A. Ford, W. F. Gresham, W. E. Grisby, G. F. Hager, J. Am. Chem. Soc., 1955, 77, 3766-3768.

[10] L. Corbel-Demailly, B. K. Ly, D. P. Minh, B. Tapin, C. Especel, F. Epron, A. Cabiac, E. Guillon, M. Besson, C. Pinel, ChemSusChem, 2013, 6, 2388-2395.
[11] J. M. Lee, P. P. Upare, J. S. Chang, Y. K. Hwang, J. Ho Lee, D. W. Hwang, D. Y. Hong, S. H. Lee, M. G. Jeong, Y. D. Kim, Y. U. Kwon, ChemSusChem, 2014, 7, 2998-3001.

[12] H. G. Manyar, C. Paun, R. Pilus, D. W. Rooney, J. M. Thompson, C. Hardacre, Chem. Commun., 2010, 46, 6279-6281.

[13] B. Rozmysłowicz, A. Kirilin, A. Aho, H. Manyar, C. Hardacre, J. Wärnå, T. Salmi, D. Y. Murzin, J. Catal., 2015, 328, 197-207.

[14] T. Turek, D. L. Trimm, N. W. Cant, Catal. Rev. Sci. Eng., 1994, 36, 645-683.

[15] B. Chen, U. Dingerdissen, J. G. E. Krauter, H. G. J. L. Rotgerink, K. Möbus, D. J. Ostgard, P. Panster, T. H. Riermeier, S. Seebald, T. Tacke, H. Trauthwein, Appl. Catal. A, 2005, 280, 17-46.

[16] G. Kresse, J. Furthmüller, Comp. Mater. Sci., 1996, 6, 15-50.

[17] G. Kresse, J. Hafner, Phys. Rev. B, 1994, 49, 14251-14269.

[18] G. Henkelman, H. Jónsson, J. Chem. Phys., 1999, 111, 7010-7022.

[19] C. M. Wang, Y. D. Wang, Y. J. Du, G. Yang, Z. K. Xie, Catal. Sci. Technol., 2015, 5, 4354-4364.

[20] B. J. Morgan, G. W. Watson, Surf. Sci., 2007, 601, 5034-5041.

[21] D. Wang, J. Jiang, H. F. Wang, P. Hu, ACS Catal., 2016, 6, 733-741.

[22] I. V. Solovyev, A. I. Liechtenstein, K. Terakura, Phys. Rev. Lett., 1998, 80, 5758-5761.

[23] C. Rödl, F. Fuchs, J. Furthmüller, F. Bechstedt, Phys. Rev. B, 2009, 79, 235114/1-235114/8.

[24] B. Wojcik, H. Adkins, J. Am. Chem. Soc., 1933, 55, 1293-1294.

[25] B. X. Peng, X. G. Yuan, C. Zhao, J. A. Lercher, J. Am. Chem. Soc., 2012, 134, 9400-9405.

[26] E. I. Gürbüz, D. D. Hibbitts, E. Iglesia, J. Am. Chem. Soc., 2015, 137, 11984-11995.

[27] L. Di, S. Yao, M. Li, G. Wu, W. Dai, G. Wang, L. Li, N. Guan, ACS Catal, 2015, 5, 7199-7207.

[28] R. Bechara, D. Balloy, J. Y. Dauphin, J. Grimblot, Chem. Mater., 1999, 11, 1703-1711.

[29] Y. Q. Ji, Z. Zhao, A. J. Duan, G. Y. Jiang, J. Liu, J. Phys. Chem. C, 2009, 113, 7186-7199.

[30] The very small hydrogen consumption at 523-673 K should be due to the reduction of trace $\mathrm{Co}^{3+}$ formed during sample pre-treatment in argon containing trace oxygen in $\mathrm{H}_{2}$-TPR experiment. The different temperature ranges of $\mathrm{Co}^{2+}$ reduction to $\mathrm{Co}^{0}$ in $\mathrm{Co}_{3} \mathrm{O}_{4}$ and $\mathrm{Co}_{3} \mathrm{O}_{4}-573$ are originated from their different textural

\section{Graphical Abstract}

Chin. J. Catal., 2018, 39: 250-257 doi: 10.1016/S1872-2067(17)63003-1

Robust cobalt oxide catalysts for controllable hydrogenation of carboxylic acids to alcohols

Song Song, Dong Wang, Lu Di, Chuanming Wang, Weili Dai, Guangjun Wu, Naijia Guan, Landong Li *

Nankai University; Shanghai Research Institute of Petrochemical Technology

The selective hydrogenation of a wide range of carboxylic acids using earth-abundant cobalt oxides through a reaction-controlled catalysis process.
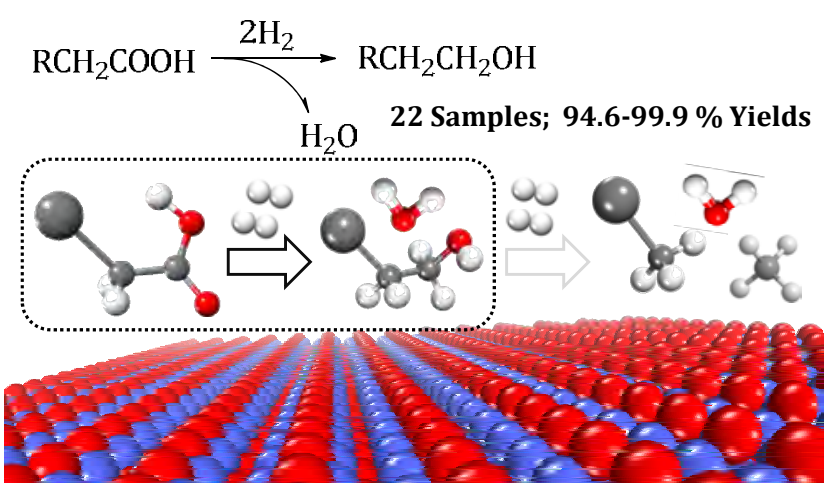
properties.

[31] B. V. Crist, Handbook of Monochromatic XPS Spectra, Wiley, New York, 2011.

[32] X. W. Xie, Y. Li, Z. Q. Liu, M. Haruta, W. J. Shen, Nature, 2009, 458, 746-749.

[33] C. Z. Yuan, L. Yang, L. R. Hou, L. F. Shen, X. G. Zhang, X. W. Lou, Energy Environ. Sci., 2012, 5, 7883-7887.

[34] M. R. Ward, E. D. Boyes, P. L. Gai, ChemCatChem, 2013, 5, 2655-2661.

[35] M. Zhang, M. de Respinis, H. Frei, Nat. Chem., 2014, 6, 362-367.
[36] S. Gao, Y. Lin, X. C. Jiao, Y. F. Sun, Q. Q. Luo, W. H. Zhang, D. Q. Li, J. L. Yang, Y. Xie, Nature, 2016, 529, 68-71.

[37] R. V. Jagadeesh, T. Stemmler, A. E. Surkus, M. Bauer, M. M. Pohl, J. Radnik, K. Junge, H. Junge, A. Brückner, M. Beller, M. Bauer, Nat. Protocol., 2015, 10, 916-926.

[38] T. Schwob, R. Kempe, Angew. Chem. Int. Ed., 2016, 55, 15175-15179.

[39] C. P. Plaisance, R. A. van Santen, J. Am. Chem. Soc., 2015, 137, 14660-14672.

[40] L. C. Liu, P. Concepción, A. Corma, J. Catal., 2016, 340, 1-9.

\section{高效钴氧化物催化羧酸可控加氢制醇}

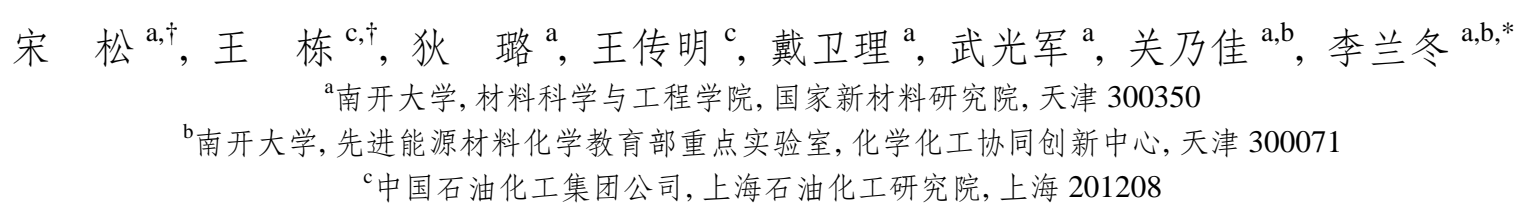

摘要: 羧酸选择加氢是合成醇的重要方法, 廉价高效的催化体系仍然在探索中. 我们利用地球上储量丰富的钴氧化物作为 催化剂, 通过控制催化反应过程, 进而实现高选择性地催化羒酸加氢制备醇. 一系列含有不同官能团的羧酸可以被选择加 氢至相应的醇类化合物, 反应选择性可以满足工业生产要求. 通过一系列的谱学表征以及理论计算, 我们证实了钴氧化物 在羧酸选择加氢反应中的优选活性位点位为氧化亚钴, 从而建立了催化剂与反应活性之间的构效关系, 为催化剂的理性设 计提供指导.

首先, 我们选取硬脂酸加氢反应作为模型反应, 通过对地球上储量丰富的氧化镍、四氧化三铁和四氧化三钴的催化活 性对比发现, 四氧化三钴催化剂活性最高, 在 $473 \mathrm{~K}, 2 \mathrm{MPa}$ 氢气条件下, 反应速率可以达到 $1.2 \mathrm{mmol} /(\mathrm{h} \cdot \mathrm{g})$. 对四氧化三钴 催化剂进行不同温度的预还原处理, 我们发现催化剂的活性得到显著提高, 其中 $573 \mathrm{~K}$ 还原的样品活性最高, 反应速率可 以达到 $7.3 \mathrm{mmol} /(\mathrm{h} \cdot \mathrm{g})$, 要远远高于贵金属催化剂 $\mathrm{Pd} / \mathrm{C}(0.6 \mathrm{mmol} /(\mathrm{h} \cdot \mathrm{g}))$ 和 $\mathrm{Pt} / \mathrm{C}(1.8 \mathrm{mmol} /(\mathrm{h} \cdot \mathrm{g}))$.

XRD 结果表明, 随着还原处理温度的不断升高, 催化剂由四氧化三钴变为氧化亚钴, 最终变为金属态的钴. 当还原温 度为 $573 \mathrm{~K}$ 时, 催化剂的组成为单一相氧化亚钴. XPS 测试结果表明, 当还原温度为 $573 \mathrm{~K}$ 时, 样品中只含有 $\mathrm{Co}^{2+}$ 的信号 峰, 并且 $\mathrm{Co} / \mathrm{O}$ 的比例为 $1 / 1$, 进一步证明样品是纯态的氧化亚钴. 从 TEM 照片中可以发现, 在原始的四氧化三钴样品中观 察到晶面间距为 0.467 和 $0.244 \mathrm{~nm}$, 分别对应四氧化三钴的 (111) 和 (311) 晶面. 而对于 $573 \mathrm{~K}$ 还原的样品只观察到一种 晶面间距 $(0.246 \mathrm{~nm})$, 对应氧化亚钴的 (111) 晶面.

结合表征手段和硬脂酸催化加氢活性结果, 我们得出氧化亚钴是 $573 \mathrm{~K}$ 还原样品催化羒酸加氢反应的活性位点. 理论 计算结果进一步证实了这个实验结论. 理论计算结果表明, 在氧化亚钴 (111) 晶面, 硬脂酸加氢转换为十八醇是非常快速 和高效的, 然而, 对于氢解 $\mathrm{C}-\mathrm{C}$ 键和 $\mathrm{C}-\mathrm{O}$ 键, 需要耗费更高的能量, 能垒约为 $1.2 \mathrm{eV}$. 因为硬脂酸的吸附远远强于十八醇 的吸附, 硬脂酸的存在会抑制十八醇氢解形成烯烃的反应, 只有当硬脂酸酸完全转化为十八醇, 才会发生随后的氢解反应. 通过控制催化反应过程, 可以实现在氧化亚钻 (111) 晶面高选择性催化酸加氢至醇, 也就是反应控制催化过程. 基于氧化 亚钴在硬脂酸加氢制备十八醇上的优异催化性能, 我们进一步研究了一系列含有不同官能团的羧酸化合物的催化加氢, 发 现氧化亚钴表现出良好的官能团容忍度, 可以实现高效、广谱的酸选择加氢至醇反应.

关键词: 选择加氢; 羧酸; 醇; 氧化钴; 反应控制催化

收稿日期: 2017-10-06. 接受日期: 2017-11-21. 出版日期: 2018-02-05.

*通讯联系人. 电话/传真: (022)23500341; 电子信箱: lild@nankai.edu.cn

†共同第一作者.

基金来源：国家自然科学基金 (21421001, 21573113); 中石化.

本文的电子版全文由Elsevier出版社在ScienceDirect上出版(http://www.sciencedirect.com/science/journal/18722067). 